\title{
BUKU AJAR AKUNTANSI SMA \\ DALAM KONTEKS KURIKULUM 2013: antara harapan dan kenyataan
}

\author{
Diana Tien Irafahmi \\ Sulastri \\ Universitas Negeri Malang \\ diana.tien.fe@um.ac.id
}

\begin{abstract}
Abstrak:
Kurikulum 2013 yang mulai diluncurkan pemerintah pada pertengahan 2013 mengamanatkan pentingnya pembelajaran yang didesain secara kolaboratif untuk membentuk siswa agar lebih produktif, kreatif, dan inovatif dengan level afektif yang tinggi. Penelitian ini bertujuan mengeksplorasi kondisi ideal yang diharapkan kurikulum 2013 disandingkan dengan kenyataan dalam dunia pendidikan utamanya pada konteks bahan ajar. 5 guru akuntansi dari 5 SMA di Kota Malang menjadi subjek penelitian ini. Data dikumpulkan dengan teknik wawancara mendalam yang dikonfirmasikan dengan hasil observasi serta dianalisis secara kualitatif. Hasil penelitian menunjukkan adanya kesenjangan antara tuntutan kurikulum dan kondisi faktual di sekolah. Rekomendasi spesifikasi bahan ajar yang perlu dikembangkan di masa mendatang juga telah dipaparkan dalam penelitian ini.
\end{abstract}

\begin{abstract}
:
The new designed curriculum, the 2013 curriculum, has been launched by Indonesian government in mid-2013. The curriculum emphasizes the importance of collaborative learning to shape students to be more productive, creative, and innovative with a high affective level. This study aims to explore the ideal condition expected by the curriculum compared to its implementation particularly in the area of learning materials. 5 accounting teachers agree to participate in the research. Data were collected by indepth interview techniques and observations which is analyzed qualitatively. The results showed the gap between the demands of the curriculum and the factual conditions at schools. Recommendations to the specifications of learning materials that needs to be developed in the future has also been. presented in this research.
\end{abstract}

Perubahan kurikulum beserta segala konsekuensi yang terjadi akibat perubahan itu selalu menarik untuk dicermati. Kurikulum 2013 yang diluncurkan pertengahan 2013 sebagai pengganti Kurikulum Tingkat Satuan Pendidikan (KTSP) telah banyak menuai pro dan kontra. Blue print tata laksana pendidikan Indonesia yang tercermin dalam Kurikulum 2013 belum dapat diterima oleh semua pihak. Inilah yang menjadi latar belakang penelitian ini: bagaimana sekolah yang dalam konteks penelitian ini 
direpresentasikan oleh guru akuntansi, mempersepsikan kurikulum baru dalam pembelajaran.

Kurikulum 2013 diarahkan untuk dapat menghasilkan insan Indonesia yang produktif, kreatif, inovatif, dan afektif melalui penguatan sikap (tahu mengapa), keterampilan (tahu bagaimana), dan pengetahuan (tahu apa) yang terintegrasi" (Kemendiknas, 2012). Kurikulum 2013 juga mengedepankan pengalaman peserta didik untuk bekerja dalam jejaringan melalui collaborative learning (Kemendiknas, 2012). Collaborative Learning merupakan pembelajaran dimana peserta didik dibiasakan bekerja sama untuk menyelesaikan masalah yang ada dalam pembelajaran. Lakey (2010:14) menyatakan bahwa “... to learn, people need revise their conceptual framework, try a new skill, unlearn an old prejudice, admit there's something they don't know...they need a group and/or a teacher that supports them”. Pernyataan Lakey tersebut mengindikasikan perlunya belajar secara kolaboratif agar individu dalam kelompok dapat saling membantu untuk merevisi konsep mereka yang salah, menciptakan kreativitas baru, dan menambah wawasan tentang hal yang belum diketahui.

Manifestasi collaborative learning ini salah satunya dapat diwujudkan dalam bentuk buku ajar yang digunakan sebagai pegangan dalam proses pembelajaran. Buku ajar tersebut dapat berisi kegiatan-kegiatan pembelajaran yang bersifat kolaboratif. Buku ajar yang digunakan di sekolah biasanya hanya memuat materi bahasan dan latihan soal, sehingga siswa kurang dapat mengembangkan kreativitasnya. Sedangkan bukuajar yang diharapkan sekarang ini adalah buku yang tidak hanya memuat materi dan latihan soal saja, tetapi juga memuat sistem penilaian dan kompetensi yang ingin dicapai serta berisi proses atau kegiatan-kegiatan dalam pembelajaran.

Dalam minat IPS di Sekolah Menengah Atas (SMA) terdapat mata pelajaran ekonomi yang memuat materi akuntansi.Ciri khas dari materi akuntansi adalah sistematik dan prosedural. Dengan demikian, pola pembelajaran yang banyak diterapkan oleh guru adalah individual learning dengan harapan siswa cepat menyerap materi.Namun hal ini berbeda dengan pandangan kurikulum 2013. Kurikulum 2013mengisyaratkan pentingnya membiasakan siswa untuk belajar secara kolaboratif. Pembelajaran secara kolaboratif diharapkan dapat mengeliminir kecurangan siswa dalam belajar misalnya cheating dan plagiat. Maka dari itu perlu adanya pengembangan 
bukuajar yang memuat proses pembelajaran yang dapat membiasakan peserta didik untuk melakukan collaborative learning.

Dalam konteks pembelajaran akuntansi, terdapat seperangkat aturan yang menjadi acuan dalam menyusun laporan keuangan. Seperangkat aturan inilah yang disebut dengan standar. Seperti halnya kurikulum yang dapat berubah sesuai dengan perkembangan jaman, standar akuntansi pun juga mengalami perubahan secara berkala disesuaikan dengan konteks sosial ekonomi suatu negara. IFRS (International Financial Reporting Standards) merupakan standar akuntansi terbaru menggantikan standar akuntansi lama yaitu GAAP (Generally Accepted Accounting Principles).IFRS ini digunakan untuk menyusun laporan keuangan yang dapat diterima secara global.Jika suatu negara menerapkan standar tersebut maka sudah barang tentu laporan yang disajikan dapat diterima, diakui dan dimengerti oleh negara diseluruh dunia. Indonesia menerapkan IFRS mulai tahun 2012, sehingga banyak perusahaan yang go public menggunakan standar tersebut. Untuk itu peserta didik yang belajar akuntansi seharusnya belajar materi akuntansi yang bermuatan IFRS.Permasalahannya, buku akuntansi untuk tingkat SMA yang telah ada di pasaran tidak dirancang dengan muatan IFRS, namun masih berkiblat pada standar akuntansi lama yaitu GAAP. Tentu saja hal ini menimbulkan masalah yaitu kesenjangan antara teori di bangku sekolah dengan praktek akuntansi sesungguhnya di lapangan.

Dari paparan di atas dapat dirumuskan beberapa hal yang melatarbelakangi pengembangan buku ajar berbasis collaborative learning dengan muatan IFRS.Pertama, pola pembelajaran akuntansi khususnya SMA masih cenderung bersifat sentralistik individualistik yang tidak sesuai dengan perubahan paradigma belajar yang mengharapkan peserta didik melakukan collaborative learningsehingga pembelajaran berpusat pada siswa. Kedua, materi akuntansi pada buku-bukuakuntansi SMA di pasaran masih belum disesuikan dengan standar akuntansi terkini yaitu IFRS.

Buku ajar yang akan dikembangkan dalam penelitian ini adalah buku ajar cetak atau non digital. Meskipun berdasarkan penelitian terdahulu di beberapa sekolah di Kota Malang yang dilakukan peneliti (Irafahmi \& Andayani, 2012; Andayani, Irafahmi \& Sulastri, 2012; Irafahmi, 2010) menunjukkan bahwa guru dan siswa percaya bahwa teknologi komputer penting dalam pembelajaran, namun penghalang terbesar untuk mengintegrasikan teknologi komputer dalam pembelajaran masih berkutat pada 
ketidaksiapan fasilitas di sekolah. Hal ini dipicu oleh rasio jumlah unit komputer dan jumlah siswa yang tidak sebanding. Selain itu, beberapa guru juga masih belum begitu terbuka dengan masuknya bahan ajar/model/media yang berbasis ICT. Dengan demikian, penelitian ini akan fokus pada pengembangan buku ajar non digital yang sifatnya low-cost namun efektif untuk menciptakan pembelajaran kolaboratif dan menyenangkan di kelas.

Berdasarkan studi pendahuluan yang telah dilakukan, guru kesulitan mendapatkan buku ajar akuntansi berbasis kolaborasi dan dirancang dengan mengadaptasi standar akuntansi IFRS.Civitas akademika Universitas Negeri Malang harus menjawab tantangan ini dengan salah satu caranya adalah mengembangkan buku ajar akuntansi berbasis collaborative learning dengan muatan IFRS.

Hasil dari penelitian pengembangan ini akan menjadi: (1) Wujud implementasi kurikulum 2013, yang berarti responsif terhadap perubahan kurikulum dengan mengembangkan produk bahan ajar, (2) Menjawab kebutuhan akan buku ajar akuntansi SMA yang disesuaikan dengan standar akuntansi terkini yaitu IFRS.

\section{Metode}

Penelitian ini menggunakan paradigma penelitian kualitatif. Setting penelitian adalah sekolah dengan lokasi penelitian di wilayah Malang kota. Subjek penelitian adalah guru akuntansi yang berjumlah 4 orang. 2 orang adalah guru dari sekolah sasaran kurikulum 2013, dan 2 guru dari sekolah yang bukan sasaran kurikulum 2013. Untuk memperkaya variasi data, maka di antara 4 guru tersebut, 2 guru adalah guru sekolah berbasis agama (MA Al Maarif-SMAK St Yusuf) dan 2 guruadalah guru sekolah umum (SMAN 8 Malang-SMA Brawijaya Smart School).

Teknik pengumpulan data dilakukan dengan wawancara mendalam, observasi dan telaah dokumen. Wawancara adalah teknik pertama yang digunakan dan kemudian dikonfirmasikan kesahihannya melalui observasi dan telaah dokumen. Analisis data dilakukan bersamaan dengan pengumpulan data melalui beberapa tahapan yang dimulai dari proses pengumpulan data, pengklasifikasian data ke dalam satuan-satuan yang sama, pereduksian data yang tidak digunakan, penyajian data dan penarikan kesimpulan atau verifikasi data (Miles and Huberman,1984) 


\section{Hasil}

\section{Analisis Kurikulum 2013}

Kurikulum 2013 mulai berlaku efektif di semua sekolah pada tahun ajaran baru 2014. Meskipun uji coba implementasi kurikulum ini telah dilakukan sejak pertengahan tahun 2013, namun optimisme sekolah tentang keberhasilan kurikulum ini masih beragam. Berdasarkan hasil wawancara dan observasi di 5 sekolah sampel, diketahui bahwa terdapat 2 sekolah sasaran (sekolah yang ditunjuk pemerintah untuk uji coba kurikulum 2013) dan 3 sekolah non sasaran kurikulum 2013.

Kendala yang dihadapi oleh sekolah/guru/siswa dalam implementasi kurikulum 2013 dapat dijabarkan sebagai berikut. Pertama, kendala dalam menjabarkan silabus ke

\section{dalam Rencana Pelaksanaan Pembelajaran (RPP).}

Kan katanya kurikulum 2013 itu akan semakin memudahkan guru. Saya tahun ini belum kebagian untuk melaksanakan kurikulum 2013. Saya hanya bisa melihat, mendengar curhatan teman-teman saya.Mereka itu lebih rempong dengan K-13 karena penilaiannya lebih detail. Terus kita juga masih harus tetap membuat RPP dan sebagainya dan sebagainya.... Padahal kata Pak Nuh, guru tidak perlu repot buat RPP...(wawancara, $13 \mathrm{Mei}$ 2014)

Karena yang kelas $\mathrm{X}$ telah dicoba menggunakan kurikulum baru, maka kami harus merubah format RPP sesuai silabus yang baru. Nah, kesulitannya di situ ...(wawancara, $19 \mathrm{Mei}$ 2014)

Sebagaimana diketahui, perubahan yang cukup drastis dari Kurikulum Tingkat Satuan Pendidikan (KTSP) ke K-13 adalah dari silabusnya. Berbeda dengan silabus pada KTSP, silabus pada K-13 memuat Kurikulum Inti (KI) yang menggantikan Standar Kompetensi (SK).Perbedaan ini tidak hanya pada segi istilah saja, namun secara substansi juga berbeda.Jika SK hanya mencakup kompetensi yang menjadi standar dalam tiap matapelajaran, maka KI mencakup 4 hal yang menjadi landasan pengembangan kompetensi dasar.4 hal tersebut adalah penghayatan dan pengamalan agama, sikap, ketrampilan dan pengetahuan.Nampak di sini bahwa pemerintah lewat K13 menginginkan adanya penguatan karakter moral spiritual dalam pendidikan.

Perbedaan yang substansial lainnya adalah pada segi kegiatan pembelajaran.Silabus K-13 mengharuskan kegiatan pembelajaran mengadopsi 
pendekatan sains (scientific approach) yang meliputi 5 tahap, berturut-turut mulai dari mengamati, menanya, mengeksplorasi, mengasosiasi, dan mengkomunikasikan. Perubahan tahapan kegiatan pembelajaran ini tentu saja akan berdampak pada perubahan RPP. Guru-guru akuntansi dari 5 sekolah sampel baik yang dari sekolah sasaran K-13 maupun yang non-sasaran menyatakan kesulitan untuk menjabarkan scientific approach dalam RPP maupun dalam proses pembelajaran yang sesungguhnya.

\begin{tabular}{|c|c|c|}
\hline Kompetensi Dasar & Materi Pokok & Pembelajaran \\
\hline $\begin{array}{l}\text { 3.3 Mendeskripsikan } \\
\text { akuntansi sebagai } \\
\text { sistem informasi } \\
\text { 4.3 Menyajikan akuntansi } \\
\text { sebagai sistem } \\
\text { informasi }\end{array}$ & $\begin{array}{l}\text { Akuntansi } \\
\text { sebagai sistem } \\
\text { Informasi } \\
\text { - Pengertian } \\
\text { Akuntansi } \\
\text { - Pemakai } \\
\text { Informasi } \\
\text { Akuntansi } \\
\text { - Karakteristik } \\
\text { pemakai } \\
\text { informasi } \\
\text { akuntansi } \\
\text { - KualitasInfor } \\
\text { masi } \\
\text { Akuntansi } \\
\text { - Prinsip } \\
\text { Dasar } \\
\text { Akuntansi } \\
\text { Bidang- } \\
\text { Bidang } \\
\text { Akuntansi } \\
\text { - Profesi } \\
\text { Akuntan } \\
\text { Etika Profesi } \\
\text { Akuntan }\end{array}$ & $\begin{array}{l}\text { Mengamati: } \\
\text { Membaca pengertian akuntansi, } \\
\text { pemakai Informasi akuntansi, } \\
\text { karakteristik, kualitas informasi } \\
\text { akuntansi, prinsip dasar akuntansi, } \\
\text { bidang-bidang akuntansi, profesi } \\
\text { akuntan dan etika profesi akuntan } \\
\text { dari laporan keuangan dan } \\
\text { berbagai sumber yang relevan } \\
\text { Menanya : } \\
\text { Mengajukan pertanyaan dan } \\
\text { berdiskusi untuk mendapatkan } \\
\text { klarifikasi tentang pengertian } \\
\text { akuntansi, pemakai Informasi } \\
\text { akuntansi, karakteristik kualitas } \\
\text { informasi akuntansi, prinsip dasar } \\
\text { akuntansi, bidang-bidang } \\
\text { akuntansi, profesi akuntan dan } \\
\text { etika profesi akuntan } \\
\text { Mengeksplorasi: } \\
\text { Mengumpulkan data dan informasi } \\
\text { tentang pengertian akuntansi, } \\
\text { pemakai Informasi akuntansi, } \\
\text { karakteritik kualitasinformasi } \\
\text { akuntansi, prinsip dasar akuntansi, } \\
\text { bidang-bidang akuntansi, profesi } \\
\text { akuntan dan etika orofesi akuntan }\end{array}$ \\
\hline
\end{tabular}

Gambar Scientific

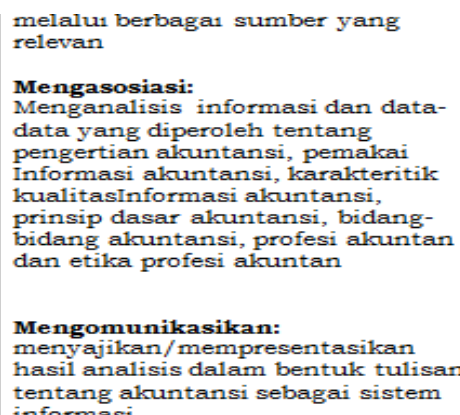

\section{Approach dalam Silabus Akuntansi}

Meskipun di silabus tersebut telah tercantum 5 tahap scientific approach, namun sifatnya masih sangat umum. Guru harus membuat detil dari masing-masing tahap ke dalam RPP sebagai panduan dalam melakukan kegiatan belajar mengajar.

Kadang jadi merasa agak bersalah juga sama anak-anak PPL, kesannya kita jadi sedikit membully ya..tolong ya RPPnya dibuatin, ntar RPPmu saya ganti namanya dengan nama saya 
Dari hasil wawancara diketahui bahwa guru cenderung pesimis untuk menerapkan scientific approach dalam matapelajaran akuntansi.Salah satu guru dari SMA Swasta menyatakan bisa menerapkan asalkan sejak jenjang pendidikan sebelumnya siswa telah terbiasa menggunakan pendekatan itu.

Kalau masalah menggunakan scientific approach....ya.... sebenarnya bisa. Cuman...gimana ya Bu?...kalau mulai awal anak-anak sudah terbiasa mengamati, terus menemukan, menanya dan sebagainya. Kalau mulai awal, sejak dini mereka terbiasa melakukan itu, saat mereka SMA mengamati saja pasti mereka sudah terbentuk (pertanyaan)... tapi saat mereka diminta untuk melakukan itu sekarang, padahal sebelum-sebelumnya mereka sudah dibiasakan untuk langsung diberi jawaban, itu agak sulit... (wawancara, 28 April 2014).

Sementara guru dari SMA Negeri sasaran K-13 yang telah melakukan uji coba penerapan justru menyatakan pendekatan scientific approach terlalu menyita waktu.

Ini masalah waktu.Sebenernya saya sih mau aja ya $\mathrm{Bu}$, bukan saya tidak mau, saya mau aja, misalnya persamaan akuntansi...eh rek wocoen, iki kalau misale gini iki diapakno, iki lek misale onok masalah seperti ini kira-kira itu diterjemahkan ke persamaan akuntansi gimana. Mereka akan mengamati, mereka akan memasukkan itu. Tapi kan butuh waktu lama, padahal kan ada tenggat waktu, kita harus ada UTS, harus ada UAS, dan kita dituntut nilai anak naik ke KKM, gitu kan. Kalau mereka diberi waktu untuk mengamati itu, berati kan tergantung pada siswa masing-masing kan..penalaran, kemampuan penalaran.... kalau anak yang cepat kan "Miss, ini ada..." di kelas itu ada anak yang mungkin logikanya dia sudah main. Jadi saat...”jurnal umum gini gini gini, oh Miss jadi lek gini gini gini, Sip.” Ada. Tapi hanya satu atau dua anak, yang lainnya harus dituntun satu persatu, harus di ajar satu persatu. Jadi balik lagi saya mau, kami mau ya, guru-guru pasti mau, tapi ada tenggat waktunya, ada...gak boleh ada limitation time gitu lho.. (wawancara, 3 Mei 2014)

Kendala kedua yang dihadapi sekolah/guru terkait implementasi K-13 adalah masalah bahan ajar. Setiap perubahan kurikulum pasti akan diikuti dengan perubahan bahan ajar. Pemerintah telah menjanjikan buku ajar K-13 akan disuplai oleh pusat. Buku ajar untuk tiap matapelajaran akan terdiri dari 2 jenis, yaitu buku pegangan guru dan buku pegangan siswa. Ketika hal ini dikonfirmasikan ke lapangan, semua guru akuntansi yang diwawancarai tidak yakin akan ketersediaan buku akuntansi dari pemerintah karena sampai dengan laporan kemajuan ini disusun, buku yang disediakan pusat untuk jenjang SMA hanyalah buku Sejarah, Bahasa Indonesia, dan Matematika. Matapelajaran ekonomi, dimana akuntansi masuk di dalamnya, sepertinya belum 
menjadi prioritas pemerintah.Berikut persepsi guru-guru akuntansi terkait bahan ajar K13.

Sejauh ini kami belum melihat bukunya secara riil ya. Jadi bukunya apa bener sesuai dengan kebutuhan kita di lapangan, jadi kita gak yakin apa itu bukunya apa pas.

Buku ekonomi dari pemerintah sepertinya tidak akan cepat datang. Soalnya kemarin juga gini, kan ini kan untuk pembelian buku kan juga diambilkan dari dana BOS. Alokasi pembelian buku untuk kurikulum 2013 itu setahu saya itu diambilkan dari BOS. Seharusnya kan gratis, tapi saya kurang tahu, untuk dana BOS yang tahun depan ini...semester depan ini kalau gak salah, itu ada sekian persen dialokasikan untuk pembelian buku kurikulum 2013. Itu mungkin karena mengunggu dari pemerintah belum datang, padahal tahun ajaran baru segera akan dimulai jadi mungkin sekolah-sekolah mengalokasikan itu dari dana BOS. Keuntungannya kan setiap siswa ada satu buku.

Berdasarkan pengalaman sepertinya yang akan duluan, yang didahulukan itu adalah yang IPA.. IPS kan lebih..berdasarkan pengalaman IPS lebih sering terpinggirkan. Kayak misal pelatihanpelatihan instruktur itu kan lebih banyak yang ke science jadi mau gak mau ya ambil kesimpulan...ya lebih ke science Itu mungkin memang salah satu planning dari pemerintah untuk menyuplai buku K-13, tapi kenyataannya sampai sekarang kita belum ada.Sama sekali belum ada.

\section{Praktek pembelajaran akuntansi di sekolah}

Kurikulum 2013 menuntut siswa untuk aktif, kreatif, dengan level afektif yang tinggi.

Diharapkan guru mengubah pendekatan dalam mengajar, yang semula teacher-centered menjadi student-centered. Ketika guru akuntansi ditanyakan apakah pendekatan yang digunakan telah berubah menjadi pembelajaran yang terpusat pada siswa, berikut jawaban mereka.

Wah...saya susah menyatakannya. Yg jelas aktivitas sy dikelas adalah menjelaskan, memberikan soal-soal, memantau pengerjaan soal dan memberi PR utk tugas siswa di rumah. Yang seperti itu teacher centered atau learner centered?

Guru masuk kelas, menjelaskan materi selama hampir separuh waktu yang tersedia, lalu memberikan latihan soal kepada siswa (biasanya latihan soal sesuai di buku ajar), dan meminta siswa untuk maju ke depan mengerjakan soal yang ada.

Definisi diberikan dulu, siklus diberikan dulu, lalu kita gambarkan dulu kan apa sih yang terjadi di hypermart, pasar....atau apapun ya 
mulai yang di bawah sampai yang modern sekarang kita tampilkan. Apa yang anda bisa ambil dari sini? Itu untuk laundry kan itu perusahaan jasa....

Kan kita gak mungkin ngelepas aja ya, kan kita disini ada target tiap bulan harus ada laporan nilai. laporannya kan bulanan...Untuk persiapan raport besar ya. Jadinya kan kami tiap bulan harus setor nilai...kami satu semester tiga kali lapor. Jadi dari awal kita itu kan punya tanggungan.... kalau misalkan kita murni student center itu sulit, sulitnya itu. Kita nunggu mereka dapat konsep itu. Apalagi mereka ini kan belum terbiasa dengan cara seperti itu. Kita kan inputnya jadi berbagai macam...SMPnya bervariasi, tempat tinggalnya juga bervariasi, dari luar pulau kan juga banyak kan. Jadi ritmenya mereka kan berbeda-beda. Jadi kalau kita gak membuat supaya ritmenya mereka searah, sejalan.Nah itu sulit nanti kita.

Berdasarkan beberapa kutipan wawancara di atas dapat diketahui bahwa guru telah berusaha mengaktifkan siswa melalui pengerjaan latihan soal. Namun, cara dalam mengaktifkan siswa belum sesuai dengan scientific approach yang dikehendaki kurikulum 2013. Dalam pendekatan sains, aktivitas pembelajaran dimulai dari 'mengamati', dilanjutkan dengan menanya, mengeksplorasi, mengasosiasi, dan mengkomunikasikan. Guru cenderung tetap menggunakan pendekatan konvensional dimana semua aktivitas pembelajaran tatap muka dimulai dari 'menjelaskan'. Ketika dikonfirmasikan dengan observasi penelitian di kelas, semua guru akuntansi memang memulai pembelajaran dengan 'menjelaskan' kemudian latihan soal yang sifatnya individual.Hal ini cukup kontradiktif dengan kurikulum 2013 yang menghendaki siswa dibiasakan belajar dalam suasana kolaboratif.

Ayo si A...kerjakan soal nomor 1 di papan tulis, si B kerjakan nomor berikutnya. Si C....coba menurut kamu, betul apa tidak jawaban si A tadi?

Berkaitan dengan penggunaan standar akuntansi terkini (IFRS) dalam pembelajaran akuntansi agar selaras dengan tuntutan kurikulum 2013 yang mengharapkan pembelajaran selalu mengikuti perkembangan ilmu pengetahuan dan teknologi serta tuntutan dunia kerja, semua guru akuntansi yang menjadi subjek penelitian menyatakan belum sepenuhnya menggunakan standar akuntansi tersebut. Berikut keterangan mereka, ketika ditanyakan apakah dalam mengajarkan akuntansi telah mengadopsi standar akuntansi terbaru. 
Belum. Karena..gimana Bu ya..kita mau pake itu di dunia pendidikan kayaknya gak ngefek, belum ada efeknya untuk anak.

Kemarin sebenarnya saya sudah memperkenalkan, tapi yang sering saya pakai tetep masih istilah lama. Saya sudah memperkenalkan ekuitas, tapi... "Miss, ekuitas ape?, Ya Allah rek modal, kan wes dijelasno rek". Misalnya apa aset "Miss, apa? Aktiva rek wes mbalik maneh aktiva". Gitu... jadi memang yang terpatri itu masih tetep yang lama, jadinya saya daripada ngulang aktiva, jadi disini juga terpatrinya nama aktiva bukan aset. Modal bukan ekuitas.

IFRS belum.Kalau IFRS itu diberikan oleh Pak Mar itu di program pengayaan.Jadi anak-anak yang....jadi pengayaan itu untuk anak-anak yang nilai akuntansi ekonomi nya sudah bagus, itu jadi mereka mempunyai semacam ekstrakurikuler, dikumpulkan untuk persiapan lomba-lomba, lomba apapunlah.Nah itu IFRS diberikan, jadi praktek pasar modal dan sebagainya.Kalau di kelas gak mungkin kita berikan.Tapi untuk tambahan pengetahuan kadang kita masih sedikit-sedikit.

Yang menarik untuk dicermati adalah, meskipun kurikulum 2013 menghendaki updating ipteks dalam pembelajaran, namun pada tahap evaluasi akhir pendidikan (Ujian Nasional SMA), soal-soal akuntansi yan dibuat pemerintah masih disajikan dengan penggunakan istilah akuntansi yang lama yang tidak sesuai dengan IFRS. Misalnya adalah penggunaan istilah harta, utang, modal masih terus muncul di soal UN, bukan aset, kewajiban ekuitas.Inilah yang menjadi pemicu utama keengganan guru untuk memperkenalkan IFRS pada siswa.Buku-buku akuntasi SMA yang ada di pasaran juga masih menggunakan istilah-istilah lama tersebut.

\section{Karakteristik pengguna buku ajar}

Salah satu syarat utama dalam desain instruksional adalah pengetahuan tentang karakteristik user. Karakteristik tersebut dapat berupa entry behavior, learning style, minat, latar belakang sosial ekonomi, kepribadian, maupun usia.

Dari segi usia, rata-rata usia siswa SMA di sekolah yang menjadi tempat penelitian adalah 15-18 tahun. Secara psikologi, usia ini tergolong masa remaja (12-21 tahun) yang merupakan masa peralihan antara masa kehidupan anak-anak dan masa kehidupan orang dewasa. Masa remaja sering dikenal dengan masa pencarian jati diri (ego identify) yang melakukan sesuatu sesuai dengan minatnya.

Ketika peneliti menanyakan kepada siswa apakah lebih berminat belajar dengan menggunakan sumber belajar cetak (printed material) seperti buku ajar atau yang non cetak, mereka menyatakan lebih berminat menggunakan versi cetak. 
Suka buku cetak.Lebih gampang. Kalau digital kan capek di mata. Saya pecinta game online sih...tapi kalau untuk belajar, untuk buku...tetap suka yang buku cetak. Beda dengan game yang full color dan ada geraknya, kalau buku kan monoton...jadi sia-sia kalau dibuat digital.

Tetep suka yang cetak lah bu. Kan banyak penjelasan guru yang ga ada di buku..nah kita sukanya langsung tulis itu di buku..di sela-sela kalimat yang ada di buku. Jadi banyak corat-coret nya buku itu..tapi coretan penting. Nah kalo elektronik kan susah di sisipi tulisan gitu.

Pernyataan siswa ini senada dengan pernyataan guru yang tetap memandang bahwa sumber belajar dalam bentuk cetak lebih utama daripada yang non-cetak.

Disini multimedia ga gitu ngefek...anak disini tdk serta merta menjadi tertarik kalo gurunya menggunakan multimedia.Meski ada tampilan multimedia, kalo mereka ndak mau...ya ndak.

versi cetak yang lebih baik menurut kami. Digital banyak risiko.Tidak punya fasilitas, kita tidak bisa memaksa anak-anak untuk itu.Yang kedua, misalkan terkena virus dan sebagainya itu juga kesulitan.Kita mungkin meminta anak mengirimkan kita melalui email, tapi antrinya berapa lama. Soalnya kita kan kelas sepuluh IPS kan lima kelas satu kelas sekitar 40 anak. Misalkan anak-anak 40 kali 5 itu 200 anak, menggunakan fasilitas sekolah, berapa lama mereka akan mengantri. Jika dirumah tidak ada laptop dan komputer, berapa lama mereka menghabiskan waktu disekolah hanya untuk mengerjakan.

Jika ditinjau dari gaya belajarnya, siswa SMA yang menjadi subjek penelitian cenderung pada tipe visual yang mudah menyerap informasi yang divisualkan. Mereka mengaku lebih mudah mengingat informasi yang dalam bentuk bagan atau gambar yang secara eksplisit divisualkan.Ini menjadi rambu-rambu atau petunjuk dalam pengembangan bahan ajar agar didesain dengan semenarik mungkin, menonjolkan bagan atau gambar yang relevan dengan materi yang diajarkan.

Latar belakang sosial ekonomi siswa cukup beragam.Dari 10 siswa yang diwawancarai, 6 siswa mengaku memiliki laptop/komputer, selebihnya tidak memiliki laptop/komputer.Pada satu SMA yang berbasis agama dimana siswanya sebagian besar 'mondok' (istilah untuk siswa yang tinggal di pondok pesantren), mereka tidak diperkenankan membawa peralatan elektronik seperti hp dan laptop selama di pondok dan di sekolah.Oleh karena itu, buku cetak menjadi rujukan utama dalam belajar. 
Pengetahuan awal (entry knowledge) siswa SMA kelas $\mathrm{X}$ tentang akuntansi adalah sangat minim.Akuntansi tidak diajarkan di SMP. Pada Kurikulum Tingkat Satuan Pendidikan, akuntansi bahkan baru diajarkan pada kelas XI SMA. Karena entry knowledge siswa masih terbatas, sehingga pada awal buku ajar, akuntansi perlu diperkenalkan secara mendalam dengan pendekatan penyajian yang menarik dan memotivasi siswa untuk belajar akuntansi.

Karakteristik siswa ditinjau dari kepribadiannya adalah beragam. Dari 10 siswa yang diwawancarai dengan diperkuat hasil observasi di kelas menunjukkan bahwa 5 siswa terlihat memiliki kepribadian ekstrovert yang dicirikan dengan sifat bersahabat, sosiabilitas, aktif bicara, menyenangkan spontan, dan ramah. 3 siswa diketahui memiliki kepribadian introvert, yang pemalu, sukar untuk menyatakan opini secara spontan, namun memiliki kontrol diri yang baik.sementara 2 siswa memiliki kepribadian neurosis dengan ciri pencemas, tegang, disertai dengan simptom fisik seperti keringat dan gugup. Pada Kurikulum 2013, siswa dituntuk untuk lebih kreatif, inovatif dan produktif serta nyaman bekerja secara kolaboratif. Membentuk karakter siswa yang demikian harus dimulai dari proses pembelajaran yang ditunjang dengan bahan ajar yang mampu mengakomodir kebutuhan itu. Mengingat di kelas selalu ada siswa dengan kepribadian introvert dan neurosis, maka pendekatan guru akuntansi yang melakukan pembelajaran secara individual (misalnya untuk pengerjaan latihan soal) justru destruktif untuk kepentingan pembentukan karakter sesuai amanat kurikulum 2013.Oleh karena itu, diperlukan buku ajar yang dapat dipedomani guru dalam melakukan pembelajaran secara kolaboratif.

\section{Sarana pembelajaran di kelas/sekolah}

Analisis ketersediaan sarana pembelajara di sekolah adalah analisis yang mengarah pada bagaimana agar bahan ajar itu relevan dengan ketersediaan fasilitas di sekolah yang menunjang pembelajaran.Berdasarkan hasil wawancara dan observasi diketahui bahwa SMA yang menjadi subjek penelitian telah memiliki sejumlah sarana pembelajaran yang memadai, seperti perpustakaan, wifi, dan LCD di kelas.Khusus untuk wifi, 1 sekolah menyatakan penggunaan wifi tertutup untuk siswa.

Wifi ada, tapi sampai sekarang tidak terbuka untuk siswa, jadi hanya untuk guru.Alasannya khawatir diselewengkan dan menyesuaikan dengan pondok. Sebgian bsar siswa sini mondok,,,,dan di pondok tidak diperbolehkan. 
Tidak seperti sekolah yang lain yang tidak memperbolehkan siswa menggunakan gadget pada saat proses pembelajaran berlangsung, 1 sekolah menyatakan sangat terbuka dalam hal penggunaan gadget.

Gadget juga diperbolehkan di pakai di kelas.Karena teknologi semakin berkembang, tidak ada batasan untuk itu....bisa sih kemana-mana (facebook-an) tergantung filter mereka aja sih.

Kondisi ini berbeda dengan sekolah-sekolah lain yang secara tegas melarang penggunaan gadget di kelas

Tidak.Disini dilarang.Alat komunikasi hanya leptop yang boleh.Kecuali itu gak boleh....karena menganggu.Siswa tidak diperbolehkan membawa hape.

Mengingat sarana pembelajaran di sekolah cukup memadai maka pengembangan bahan ajar sedapat mungkin memberikan peluang pada siswa untuk melakukan eksplorasi dengan memperkaya pengetahuan lewat sumber belajar lain selain yang ada di buku. Menyisipkan instruksi di buku ajar seperti "carilah informasi berikut di internet dan analisislah.." atau "pergilah ke koperasi di sekolahmu, dan amati bagaimana pengelola koperasi mencatat penerimaan dan pengeluaran di koperasi.." merupakan hal yang penting untuk dilakukan.

Dalam hal ketersediaan buku ajar, semua sekolah yang menjadi subjek penelitian menyatakan tidak mewajibkan siswa untuk membeli buku A atau B. Namun, siswa biasanya akan menggunakan buku sesuai yang digunakan oleh guru. Pada 1 sekolah, guru hanya meminta siswa meminjam buku akuntansi di perpustakaan untuk dipelajari saat proses pembelajaran berlangsung. Namun tidak semua siswa mendapatkan buku tersebut karena rasio buku di perpustakaan dengan siswa adalah 1:2.

Ekspektasi guru terhadap buku ajar yang akan dikembangkan peneliti cukup beragam, diantaranya adalah:

- Buku yang bisa memotivasi siswa.

Susah sekali memotivasi siswa untuk belajar akuntansi.Bagi siswa, belajar agama lebih utama daripada belajar akuntansi.

Saya itu selalu bilang gini ke anak2: ibu itu pngen ada alumni sini yang masuk STAN gitu lho....

Trus anak-anak malah bilang: percuma bu..jadi pegawai pajak malah jadi kayak gayus gitu....(pdhl gayus kan cuma oknum)

- Buku yang mengaitkan agama dg akuntansi. 
- Buku yang lebih updating pengetahuan. Materi buku-buku yang ada sepertinya sama saja...tidak ada yang berubah. Hanya cetakan baru saja...namun isi tdk up to date

- Buku yang dilengkapi cd/digital: berisi materi untuk membantu guru menjelaskan di kelas. Buku versi cetak sebaiknya banyak berisi latihan-latihan soal yang variatif

- Dari banyak buku akuntansi ini kok ndak ada ya yang secara runtut menjelaskan sejarah akuntansi dari lucas pacioli trus sampai ke indonesia itu bagaimana?

- saya pengen nyari buku itu yang ada step mulai awal sampai akhir. Jadi satu soal mulai dari jurnal umum sampai dia membuat laporan keuangan, itu satu siklus itu ada. Tapi itu carinya susah. iya terpisahpisah. Jadi jurnal umum ada sendiri latihan soalnya, nanti...untuk neraca saldo bikin lagi dan seterusnya. Saya belum nemu gitu, yang satu siklus lengkap sampai ke jurnal pembaliklah kalau bisa, kalau ada.

- Buku dipasaran materinya cukup, tapi latihan soal kurang.

- Kita pengennya ada yang terpisah, Cuma memang kalau yang terpisah..kan disemester satu ekonomi, semester dua akuntansi. Saat semester dua akuntansi ini buku yang semester dua ini sudah mulai langkah dan penerbit sudah mulai enggan menawarkan. Kan penerbit kan menawarkan diawal, jadi saat kita semester dua, kita sudah mulai "kita nyari dimana nih?" Di togamas sudah limited edition. Jadi kemarin dua periode kita, ya sudahlah ambil aja yang satu tahun, kita ambil yang ekonomi dan akuntansi. Karena kita gak mau kehilangan buku.

Hasil analisis kebutuhan yang telah dipaparkan di atas, dapat diringkas dalam tabel berikut.

Tabel 5.1 Ringkasan analisis kebutuhan

\begin{tabular}{|c|c|c|c|}
\hline No. & $\begin{array}{c}\text { Kondisi ideal sesuai } \\
\text { tuntutan Kurikulum } \\
2013\end{array}$ & Kondisi faktual di sekolah & Kebutuhan \\
\hline 1. & $\begin{array}{lr}\text { Silabus } & \mathrm{K}-13 \\
\text { mengharuskan kegiatan } & \\
\text { pembelajaran mengadopsi } \\
\text { pendekatan sains } \\
\text { (scientific approach) yang } \\
\text { meliputi 5 tahap, berturut- } \\
\text { turut mulai dari } \\
\text { mengamati, menanya, } \\
\text { mengeksplorasi, } \\
\text { mengasosiasi, dan } \\
\text { mengkomunikasikan }\end{array}$ & $\begin{array}{l}\text { Guru-guru akuntansi kesulitan } \\
\text { untuk menjabarkan scientific } \\
\text { approach dalam RPP maupun } \\
\text { dalam proses pembelajaran } \\
\text { yang sesungguhnya. }\end{array}$ & $\begin{array}{l}\text { Buku ajar yang dirancang } \\
\text { dengan pendekatan scientific } \\
\text { approach (bisa juga } \\
\text { dituangkan pada medianya, } \\
\text { bukan pada bukunya) dan } \\
\text { dilengkapi contoh RPP } \\
\text { scientific approach }\end{array}$ \\
\hline
\end{tabular}




\begin{tabular}{|c|c|c|c|}
\hline 2. & $\begin{array}{lr}\text { Buku ajar } & \text { tiap } \\
\text { matapelajaran } & \text { disuplai } \\
\text { oleh pemerintah } & \end{array}$ & $\begin{array}{l}\text { Buku yang disediakan pusat untuk } \\
\text { jenjang SMA hanyalah buku } \\
\text { Sejarah, Bahasa Indonesia, dan } \\
\text { Matematika. Buku } \\
\text { ekonomi/akuntansi belum ada. }\end{array}$ & $\begin{array}{l}\text { Buku ajar yang adaptif } \\
\text { dengan kurikulum } 2013\end{array}$ \\
\hline 3. & $\begin{array}{l}\text { Siswa dibiasakan belajar } \\
\text { dalam suasana kolaboratif } \\
\text { agar menjadi pribadi yang } \\
\text { aktif, kreatif, inovatif. }\end{array}$ & 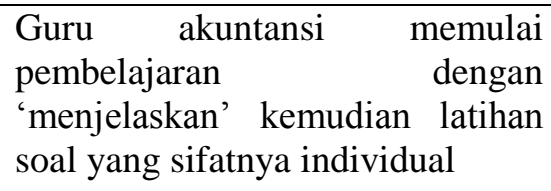 & $\begin{array}{lcr}\text { Buku ajar } & \text { yang memuat } \\
\text { kegiatan } & \text { pembelajaran } \\
\text { kolaboratif } & \end{array}$ \\
\hline 4. & $\begin{array}{l}\text { Pembelajaran harus } \\
\text { mengikuti perkembangan } \\
\text { ilmu pengetahuan serta } \\
\text { tuntutan dunia kerja. Pada } \\
\text { konteks akuntansi } \\
\text { misalnya dengan } \\
\text { penggunaan IFRS. }\end{array}$ & $\begin{array}{lrr}\text { Guru akuntansi } & \text { belum } \\
\text { menggunakan IFRS dan } \\
\text { cenderung enggan menggunakan } \\
\text { karena soal UN masing } \\
\text { menggunakan pengetahuan lama. }\end{array}$ & $\begin{array}{lr}\text { Buku ajar } & \text { yang berisi } \\
\text { pengetahuan } & \text { kontemporer } \\
\text { diantaranya } & \text { dengan } \\
\text { pengenalan } & \text { istilah-istilah } \\
\text { akuntansi baru } & \text { sesuai IFRS } \\
\text { dengan tidak } & \text { mengeliminasi } \\
\text { istilah lama } & \end{array}$ \\
\hline 5. & $\begin{array}{l}\text { Menggunakan teknologi } \\
\text { dalam pembelajaran }\end{array}$ & 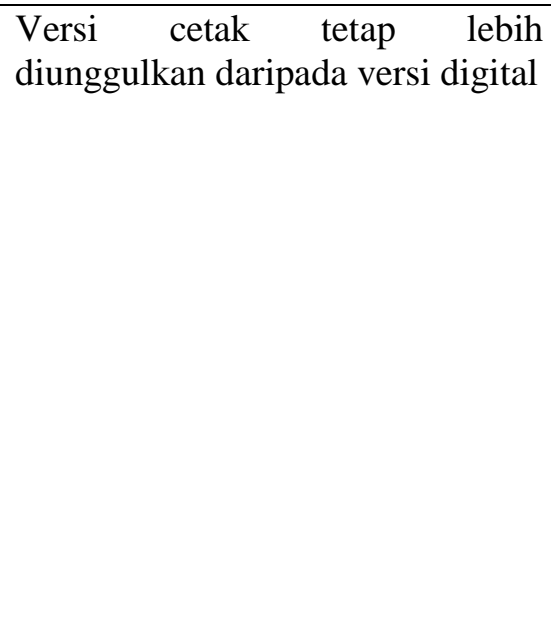 & $\begin{array}{l}\text { Bahan ajar dikemas dalam } \\
\text { bentuk buku yang sesuai } \\
\text { dengan karakteristik siswa } \\
\text { (menonjolkan bagan atau } \\
\text { gambar yang relevan dengan } \\
\text { materi yang diajarkan, } \\
\text { menarik dan memotivasi } \\
\text { siswa untuk belajar } \\
\text { akuntansi) dengan tetap } \\
\text { memuat pengetahuan yang } \\
\text { memungkinkan riswa } \\
\text { mengeksplorasi sumber } \\
\text { belajar lain (internet, } \\
\text { perpustakaan, dll) }\end{array}$ \\
\hline
\end{tabular}

DAFTAR PUSTAKA

Andayani, E.S., Irafahmi, D.T., Sulastri. 2012. Pengembangan bahan ajar matakuliah praktikum pengantar akuntansi dengan program microsoft visual basic. Jurnal Pendidikan Akuntansi (JPA). Vol. 1 No. 1 Maret 2012. Hal. 14-22

Ankarath et al. 2012.Memahami IFRS. Jakarta: PT. Indeks.

Badan Standar Nasional Pendidikan.2006. Standar Kompetensi dan Kompetensi

Dasar SMA/MA.(Online), (http://bsnp-indonesia.org), diakses 23 April 2012.

Borg, W. \& Gall, M. 1983.Educational Research: An Introduction 4th edition. Longman Inc.: New York

Departemen Pendidikan Nasional.2006. Pengembangan Bahan Ajar.(Online), (www.dikti.go.id/files/atur/KTSP-SMK/11.ppt), diakses tanggal 23 April 2012.

Hamalik, Oemar. 2008. Dasar-dasar Pengembangan Kurikulum. Bandung:

PT. Remaja Rosdakarya.

Irafahmi, D.T. 2010. The complexity ini adopting new technological program in education. Jurnal Ilmu Pendidikan (JIP). Jilid 17 No. 2, Juni 2010. Hal 94-100 
Irafahmi, D.T., Andayani, E.S. 2012. Pengembangan bahan ajar akuntansi berbasis komputer untuk SMK program keahlian bisnis dan manajemen se-Kota Malang. Jurnal Pendidikan Akuntansi (JPA). Vol. 1 No. 2 September 2012. Hal. 83-90

Johnson at al. 2012.Collaborative Learning. Bandung: Nusamedia.

Kemdiknas (Kementerian Pendidikan Nasional). 2012. Draft Kurikulum 2013.

(Online), (http://dikmen.kemdiknas.go.id), diakses tanggal 20 Januari

Kurniawan, Khaerudin. 2006. Handout Mata Kuliah Menulis Bahan Ajar/Ilmiah. UPI: FPBS, (Online), (http://file.upi.edu/Direktori/FPBS), diakses 3 Februari 2013.

Lakey, George. 2010. Facilitating Group Learning. San Francisco: Jossey Bass.

Miles, M.B. \& Huberman, A.M. 1984. Quality Data Analysis. London: Sage Publication

Muslich, Mansur. 2009. Text Book Writing. Yogyakarta: Ar_Ruzz Media.

Prastowo, Andi. 2012. Panduan Kreatif Membuat Bahan Ajar Inovatif. Y Yogakarta: Diva Press.

Sanjaya, Wina. 2008. Pembelajaran dalam Implementasi Kurikulum Berbasis Kompetensi. Jakarta: Kencana Prenada Media Group.

Sudjana, N. 1990.Penilaian Hasil Proses Belajar Mengajar. Bandung: Remaja Rosdakarya.

Terenzini et al. 2001. Collaborative Learning vs Lecture: students' reported learning gains.Journal of Enginering education, (Online), (http://barnard.edu), diakses 13 Januari 2013.

UCIDT. 1973. Instructional Development Institute Model. Syracuse: the University Consortium

for Instructional Development \& Technology

Undang-Undang RI No. 20 Tahun 2003 tentang Sistem Pendidikan Nasional. Jaringan Dokumentasi dan Informasi Badan Pemeriksa Keuangan Republik Indonesia. (Online), (http://www.jdih.bpk.go.id), diakses 12 Januari 2014 